International Research Journal of Management, IT \& Social Sciences
Available online at https://sloap.org/journals/index.php/irjmis/
Vol. 9 No. 2, March 2022, pages: 264-273
ISSN: 2395-7492
https://doi.org/10.21744/irjmis.v9n2.2038

\title{
Service Quality Delivery and Consumers' Choice of Fast-food Outlets
}

Aniebiet Etuk

Joseph A. Anyadighibe

Christian Amadi ${ }^{c}$

Edim Eka James ${ }^{d}$

Article history:

Submitted: 09 November 2021

Revised: 18 December 2021

Accepted: 27 January 2022

\section{Keywords: \\ assurance; \\ consumer choice; \\ empathy; \\ reliability; \\ responsiveness, \\ tangibility;}

\begin{abstract}
This study examined the effect of service quality delivery on consumer's choice of fast foods outlets. Cross-sectional survey research design was adopted. Primary data was collected from respondents using structured questionnaire. Simple regression in the Statistical Package for Social Science (SPSS) was adopted to analyze the data collected. Consequently, it was found that service tangibility, reliability, responsiveness, assurance and empathy had significant effects on consumer's choice of fast foods. Thus, it was recommended amongst others, that fast food outlets should be more responsive to consumers' service requirements by rapidly eliciting and resolving consumers' enquiries and complaints; consistently deliver fast, strong and reliable service; ensure their personnel treat consumers with politeness and consideration at every point of service encounter and constantly seek ways to offer freshness in order to remain relevant in the market place.
\end{abstract}

International research journal of management, IT and social sciences (C) 2022. This is an open access article under the CC BY-NC-ND license (https://creativecommons.org/licenses/by-nc-nd/4.0/).

Corresponding author:

Edim Eka James,

Department of Marketing, University of Calabar, Nigeria.

Email address: jamesedim@gmail.com

\footnotetext{
Department of Marketing, Akwa Ibom State University, Nigeria

Department of Marketing, University of Calabar, Nigeria

Department of Business Administration, Federal University Wukari, Taraba State, Nigeria

Department of Marketing, University of Calabar, Nigeria 


\section{Introduction}

The opening of what can be referred to as the first modern fast food outlet in Nigeria in 1986, by Mr. Bigg's, a subsidiary of UAC Nigeria, could be regarded as a turning point in the social wellbeing of the citizens as well as a significant landmark in the economic history of the country. Since then, the Nigerian business environment has never remained the same again. It has witnessed continuous establishment of various fast food joints, fondly referred to as eateries in virtually every nooks and crannies of the country. A glance at any street corner in Nigeria, now, especially in the urban centres, may likely reveal at least two eateries with their front-lit menu boards jostling for customers' attention. At present, there are over 150 brand names in the country. Also, the South western Nigeria alone accommodates nothing less than 500 outlets of different sizes established by corporate individuals and organizations (Fakokunde, 2010). Customer's assessment of service quality is a critical information for service providers whose aim is to improve business performance, strengthen core competencies and position themselves more strategically in the market place (Cronin \& Taylor 1992; Jain \& Gupta 2004). Organizations that provide superior service quality do experience higher economic returns and also have a more satisfied customer base (Aaker \& Jacobson, 1994; Gilbert \& Veloutsou, 2006). Therefore, it has become ubiquitous for service providers to seek out competitive advantages by providing superior service (Lee \& Hing, 1995). According to Zeithaml (1988), service quality is usually defined as the customer's judgement of the overall excellence or superiority of the service. Barrows \& Power (2008), suggested that service is particularly a pivotal or fundamental element in the restaurant sector. In order to measure service quality, Parasuraman et al. (1988), have developed an instrument called SERVQUAL which consists of five dimensions: reliability, responsiveness, empathy, assurance and tangibles. While Nikolich \& Sparks (1995), have stated that perceived levels of service in restaurants are based on the relationship between customers and service providers (Hur et al., 2006; Styvén, 2010).

For Anyanwu (1993), every organization sets out to offer good quality goods and services. As the organizations offer these goods and services to the consumers, they expect reactions from the consumers to confirm or disconfirm the quality of their products. The good quality offerings of a firm bring about good service result, which is customer satisfaction and affects consumers' choice. Customer satisfaction is defined as the number of customers, or percentage of total customers, whose reported experience with a firm, its products, or its services (ratings) exceeds specified satisfaction goals. It is seen as a key performance indicator within business and is often part of a balanced scorecard. In a competitive market place, where business competes for customers, customer satisfaction is seen as a key differentiator and increasingly has become a key element of business strategy. The modern fast food industry is highly commercialized and characterized by various pre-formulated procedures and food preparation methods usually set up with the intention of minimizing production cost and delivery time. The concern here is, little or no attention is paid to the generation and analysis of information about customers encounter and possible ways of dislodging negative dissonance. Hence, this study on the effect of service quality delivery on consumers' choice of fast foods outlets was aimed at ascertaining how the various SERVQUAL dimensions which ranges from tangibility, reliability, responsiveness, assurance and empathy in relation to the service offerings peculiar to the fast-food outlets enhances consumers' choice to buy again, become less price sensitive, use positive word of mouth about the offerings provided by fast food outlet (Rackwitz, 2001; Husted et al., 2000).

\section{Review of related literature SERVQUAL model}

Parasuraman et al. (1985), postulated the SERVQUAL model. SERVQUAL is presented as a multidimensional construct. In the original formulation, Parasuraman et al. (1985), identified ten components of SERVQUAL: reliability, responsiveness, competence, access, courtesy, communication, credibility, security, understanding/knowing the customer and tangibles. In their 1988 work, these components were collapsed into five dimensions: reliability, assurance, tangibles, empathy and responsiveness. Reliability is the dependability, accuracy and consistency of performance of fast foods outlets. Tangibility is the physical appearance of element like fast-food outlets. Responsiveness is promptness and helpfulness. Empathy means easy access, good communication, convenience and customer understanding. It involves the ease and convenience in assessing quality service delivery which will positively influence consumers' choice of fast food. Assurance involves credibility, security, competence and courtesy exhibited by fast-food outlets.

Etuk, A., Anyadighibe, J. A., Amadi, C., \& James, E. J. (2022). Service quality delivery and consumers' choice of fast-food outlets. International Research Journal of Management, IT and Social Sciences, 9(2), 264-273. 


\section{Expectation disconfirmation theory}

The expectation disconfirmation theory was postulated (Oliver Richard, 1997; Oliver, 1981). This theory posits that expectations, coupled with perceived performance, lead to post-purchase satisfaction/choice. Expectation disconfirmation occurs in three (3) forms:

1. Positive disconfirmation: Occurs when perceived performance exceeds expectations.

2. Confirmation: Occurs when perceived performance meets expectations.

3. Negative disconfirmation: Occurs when perceived performance does not meet and is less than the expectations.

\section{Materials and Methods}

A survey research design was used in this study by collecting data through questionnaire from the population of interest. The design is appropriate for investigating phenomena as they exist in real life helps in collecting the views, opinions and perspectives of the respondents regarding this research. The administration of the questionnaire was done using a convenience sampling technique for one hundred (100) respondents. The copies of questionnaires were administered to respondents at different eateries in Calabar. The research instrument was divided into two sections: A and B. Section A included the bio-data (gender, age, marital status, educational qualification and income) of respondents. While the section B was made up of statements about in order to elicit individual opinions from respondents on how these variables of s service tangibility (items 6-9), service reliability (items 10-13), service responsiveness (items 14-17), service assurance (items 18-21) and service empathy (items 22-25) affect consumers' choice (26-29) of fast foods outlets. The opinions of the respondents were subjected to Strongly Agree (SA), Agree (A), Disagree (D) and Strongly Disagree (SD). The data treatment was done using the simple regression analysis (Wright \& Young, 1997; Huq et al., 2008).

\section{Results and Discussions}

$\mathrm{H}_{1}$ : Service tangibles do not have any significant effect on consumers' choice of fast-food outlets.

Table 1

Model summary showing the effect of service tangibility on consumers' choice of fast-food outlets

\begin{tabular}{lcccc}
\hline Model & R & R square & Adjusted R square & Std. error of the estimate \\
\hline 1 & $.725^{\text {a }}$ & .526 & .521 & .79564 \\
a. Predictors: (Constant), Tangibility & & \\
\hline
\end{tabular}

Table 2

ANOVA $^{\text {a }}$ showing the effect of service tangibility on consumers' choice of fast-food outlets

\begin{tabular}{llccccc}
\hline & Model & Sum of Squares & Df & Mean Square & F & Sig. \\
\hline 1 & Regression & 65.275 & 1 & 65.275 & 103.113 & $.000^{\mathrm{b}}$ \\
Residual & 58.873 & 93 & .633 & & \\
$\quad$ Total & 124.147 & 94 & & & \\
a. Dependent Variable: Consumers' choice & & & \\
b. Predictors: (Constant), Tangibility & & & & \\
\hline
\end{tabular}


Table 3

Coefficients $^{\mathrm{a}}$ showing the effect of service tangibility on consumers' choice of fast-food outlets

\begin{tabular}{lccccc}
\hline \multicolumn{1}{c}{ Model } & \multicolumn{2}{c}{$\begin{array}{c}\text { Unstandardized } \\
\text { Coefficients }\end{array}$} & \multicolumn{2}{c}{$\begin{array}{c}\text { Standardized } \\
\text { Coefficients } \\
\text { Beta }\end{array}$} & t \\
& B & Std. Error & Big. & \\
\hline $1 \quad$ (Constant) & 2.057 & .406 & & 5.067 & .000 \\
Tangibility & .635 & .063 & .725 & 10.154 & .000 \\
a. Dependent Variable: Consumers' choice & & & \\
\hline
\end{tabular}

Tables 1, 2 and 3 above report the results of regression analysis carried out to test Hypothesis 1 . The results show that Service tangibles do have significant effect on consumers' choice of fast-food outlets. $(b=2.057, p<0.05)$. Therefore, Hypothesis 1 is rejected. Tables 2 and 3 further report a significant F statistic, indicating the model's strong prediction strength $(\mathrm{F}=103.113, \mathrm{R} 2=72.5 \%, \mathrm{p}<0.05)$. The R2 of 72.5 per cent implies that for every unit change in consumers' choice of fast food, 72.5 per cent of such variation is attributed to Service tangibles (Decety \& Cowell, 2014; Singer \& Klimecki, 2014).

$\mathrm{H}_{2}$ : Service reliability does not have any significant effect on consumers' choice of fast-food outlets.

Table 4

Model summary showing the effect of service reliability on consumers' choice of fast-food outlets

\begin{tabular}{lcccc}
\hline Model & R & R square & Adjusted R square & Std. error of the estimate \\
\hline 1 & $.631^{\mathrm{a}}$ & .398 & .392 & .89613 \\
a. Predictors: (Constant), Reliability & & \\
\hline
\end{tabular}

Table 5

ANOVA ${ }^{\mathrm{a}}$ showing the effect of service reliability on consumers' choice of fast-food outlets

\begin{tabular}{ccccccc}
\hline & Model & Sum of Squares & Df & Mean Square & F & Sig. \\
\hline 1 & Regression & 49.463 & 1 & 49.463 & 61.594 & $.000^{\mathrm{b}}$ \\
& Residual & 74.684 & 93 & .803 & & \\
\multicolumn{2}{l}{ Total } & 124.147 & 94 & & & \\
a. Dependent Variable: Consumers' choice & & & & \\
b. Predictors: (Constant), Reliability & & & & \\
\hline
\end{tabular}

Table 6

Coefficients ${ }^{\mathrm{a}}$ showing the effect of service reliability on consumers' choice of fast-food outlets

\begin{tabular}{|c|c|c|c|c|c|}
\hline \multirow[t]{2}{*}{ Model } & $\begin{array}{r}\text { Uns } \\
\mathrm{Cc}\end{array}$ & $\begin{array}{l}\text { ardized } \\
\text { cients }\end{array}$ & \multirow{2}{*}{$\begin{array}{c}\text { Standardized } \\
\text { Coefficients } \\
\text { Beta }\end{array}$} & \multirow[t]{2}{*}{$\mathrm{t}$} & \multirow[t]{2}{*}{ Sig. } \\
\hline & $\mathrm{B}$ & Std. Error & & & \\
\hline 1 (Constant) & 2.891 & .418 & & 6.908 & .000 \\
\hline Reliability & .519 & .066 & .631 & 7.848 & .000 \\
\hline
\end{tabular}

Tables 4, 5 and 6 above report the results of regression analysis carried out to test Hypothesis 2 . The results show that Service reliability does have significant effect on consumers' choice of fast-food outlets. $(b=2.891, p<0.05)$. Therefore, Hypothesis 2 is rejected. Tables 5 and 6 further report a significant F statistic, indicating the model's strong prediction strength $(\mathrm{F}=61.594, \mathrm{R} 2=63.1 \%, \mathrm{p}<0.05)$. The $\mathrm{R} 2$ of 63.1 per cent implies that for every unit change in consumers' choice of fast food, 63.1 per cent of such variation is attributed to Service reliability (Bartels \& Johnson, 2015; Foxall, 2003).

Etuk, A., Anyadighibe, J. A., Amadi, C., \& James, E. J. (2022). Service quality delivery and consumers' choice of fast-food outlets. International Research Journal of Management, IT and Social Sciences, 9(2), 264-273. 
$\mathrm{H}_{3}$ : Service responsiveness does not have any significant effect on consumers' choice of fast-food outlets.

Table 7

Model summary showing the effect of service responsiveness on consumers' choice of fast-food outlets

\begin{tabular}{lcccc}
\hline Model & R & R square & Adjusted R square & Std. error of the estimate \\
\hline 1 & $.764^{\mathrm{a}}$ & .584 & .580 & .74507 \\
a. Predictors: (Constant), Responsiveness & & \\
\hline
\end{tabular}

Table 8

ANOVA ${ }^{\text {a }}$ showing the effect of service responsiveness on consumers' choice of fast-food outlets

\begin{tabular}{llccccc}
\hline & Model & Sum of Squares & Df & Mean Square & F & Sig. \\
\hline 1 & Regression & 72.521 & 1 & 72.521 & 130.639 & $.000^{\mathrm{b}}$ \\
& Residual & 51.627 & 93 & .555 & & \\
& Total & 124.147 & 94 & & &
\end{tabular}

a. Dependent Variable: Consumers' choice

b. Predictors: (Constant), Responsiveness

Table 9

Coefficients ${ }^{\mathrm{a}}$ showing the effect of service responsiveness on consumers' choice of fast-food outlets

\begin{tabular}{lccccc}
\hline \multicolumn{1}{c}{ Model } & \multicolumn{2}{c}{$\begin{array}{c}\text { Unstandardized } \\
\text { Coefficients }\end{array}$} & $\begin{array}{c}\text { Standardized } \\
\text { Coefficients } \\
\text { Beta }\end{array}$ & $\mathrm{t}$ & Sig. \\
& $\mathrm{B}$ & Std. Error & Beta & \\
\hline 1 (Constant) & 1.311 & .425 & & 3.082 & .003 \\
\multicolumn{1}{c}{ Responsiveness } & .786 & .069 & .764 & 11.430 & .000 \\
a. Dependent Variable: Consumers' choice & & & \\
\hline
\end{tabular}

Tables 7, 8 and 9 above report the results of regression analysis carried out to test Hypothesis 3 . The results show that Service responsiveness have significant effect on consumers' choice of fast-food outlets $(b=1.311, p<0.05)$. Therefore, Hypothesis 3 is rejected. Tables 8 and 9 further report a significant $F$ statistic, indicating the model's strong prediction strength $(\mathrm{F}=130.639, \mathrm{R} 2=76.4 \%, \mathrm{p}<0.05)$. The $\mathrm{R} 2$ of 76.4 per cent implies that for every unit change in consumers' choice of fast food, 76.4 per cent of such variation is attributed to service responsiveness (Sipayung et al., 2021; Yulianti et al., 2020).

$\mathrm{H}_{4}$ : Service assurance does not have any significant effect on consumers' choice of fast-food outlets.

Table 10

Model summary showing the effect of service assurance on consumers' choice of fast-food outlets

\begin{tabular}{lcccc}
\hline Model & R & R square & Adjusted R square & Std. error of the estimate \\
\hline 1 & $.534^{\mathrm{a}}$ & .285 & .278 & .97671 \\
a. Predictors: (Constant), Assurance & & \\
\hline
\end{tabular}

Table 11

ANOVA ${ }^{a}$ showing the effect of service assurance on consumers' choice of fast-food outlets

\begin{tabular}{ccccccc}
\hline & Model & Sum of Squares & Df & Mean Square & F & Sig. \\
\hline 1 & Regression & 35.429 & 1 & 35.429 & 37.139 & $.000^{\mathrm{b}}$ \\
& Residual & 88.718 & 93 & .954 & & \\
& Total & 124.147 & 94 & & & \\
a. Dependent Variable: Consumers' choice & & & & \\
b. Predictors: (Constant), Assurance & & & & \\
\hline
\end{tabular}


Table 12

Coefficients $^{\mathrm{a}}$ showing the effect of service assurance on consumers' choice of fast-food outlets

\begin{tabular}{|c|c|c|c|c|c|}
\hline \multirow[t]{2}{*}{ Model } & \multicolumn{2}{|c|}{$\begin{array}{l}\text { Unstandardized } \\
\text { Coefficients }\end{array}$} & \multirow{2}{*}{$\begin{array}{c}\text { Standardized } \\
\text { Coefficients } \\
\text { Beta }\end{array}$} & \multirow[t]{2}{*}{$\mathrm{t}$} & \multirow[t]{2}{*}{ Sig. } \\
\hline & B & Std. Error & & & \\
\hline 1 (Constant) & 3.351 & .461 & & 7.263 & .000 \\
\hline Assurance & .439 & .072 & .534 & 6.094 & .000 \\
\hline
\end{tabular}

Tables 10, 11 and 12 above report the results of regression analysis carried out to test Hypothesis 4. The results show that service assurance have significant effect on consumers' choice of fast-food outlets. $(b=3.351, p<0.05)$. Therefore, Hypothesis 4 is rejected. Tables 11 and 12 further report a significant F statistic, indicating the model's strong prediction strength $(\mathrm{F}=37.139, \mathrm{R} 2=53.4 \%, \mathrm{p}<0.05)$. The $\mathrm{R} 2$ of 53.4 per cent implies that for every unit change in consumers' choice of fast food, 53.4 per cent of such variation is attributed to service assurance.

$\mathrm{H}_{5}$ : Service empathy does not have any significant effect on consumers' choice of fast-food outlets.

Table 13

Model summary showing the effect of service empathy on consumers' choice of fast-food outlets

\begin{tabular}{lcccc}
\hline Model & R & R square & Adjusted R square & Std. error of the estimate \\
\hline 1 & $.455^{\mathrm{a}}$ & .207 & .199 & 1.02859 \\
a. Predictors: (Constant), Empathy & & \\
\hline
\end{tabular}

Table 14

ANOVAa showing the effect of service empathy on consumers' choice of fast-food outlets

\begin{tabular}{llccccc}
\hline & Model & Sum of Squares & Df & Mean Square & F & Sig. \\
\hline 1 & Regression & 25.754 & 1 & 25.754 & 24.343 & $.000^{\mathrm{b}}$ \\
& Residual & 98.393 & 93 & 1.058 & & \\
& Total & 124.147 & 94 & & & \\
a. Dependent Variable: Consumers' choice & & & & \\
b. Predictors: (Constant), Empathy & & & & \\
\hline
\end{tabular}

Table 15

Coefficientsa showing the effect of service empathy on consumers' choice of fast-food outlets

\begin{tabular}{|c|c|c|c|c|c|}
\hline \multirow[t]{2}{*}{ Model } & \multicolumn{2}{|c|}{$\begin{array}{l}\text { Unstandardized } \\
\text { Coefficients }\end{array}$} & \multirow{2}{*}{$\begin{array}{c}\text { Standardized } \\
\text { Coefficients } \\
\text { Beta }\end{array}$} & \multirow[t]{2}{*}{$\mathrm{t}$} & \multirow[t]{2}{*}{ Sig. } \\
\hline & $\mathrm{B}$ & Std. Error & & & \\
\hline 1 (Constant) & 3.780 & .481 & & 7.860 & .000 \\
\hline Empathy & .395 & .080 & .455 & 4.934 & .000 \\
\hline a. Dependent & Consu & rs' choice & & & \\
\hline
\end{tabular}

Tables 13, 14 and 15 above report the results of regression analysis carried out to test Hypothesis 5. The results show that service empathy does have significant effect on consumers' choice of fast-food outlets. $(b=3.780, p<0.05)$. Therefore, Hypothesis 5 is rejected. Tables 14 and 15 further report a significant F statistic, indicating the model's strong prediction strength $(\mathrm{F}=24.343, \mathrm{R} 2=45.5 \%, \mathrm{p}<0.05)$. The $\mathrm{R} 2$ of 45.5 per cent implies that for every unit change in consumers' choice of fast food, 45.5 per cent of such variation is attributed to service empathy.

Etuk, A., Anyadighibe, J. A., Amadi, C., \& James, E. J. (2022). Service quality delivery and consumers' choice of fast-food outlets. International Research Journal of Management, IT and Social Sciences, 9(2), 264-273. 


\section{Discussion of findings}

The finding of this study is in congruence with other related studies. The study shows that service tangibles do have significant effect on consumers' choice of fast-food outlets. This finding is in line with the work of Bougoure \& Neu (2010) in their study on the relationship between service quality and customer satisfaction in the Malaysian fast food industry. 300 students from a large Malaysian University in the Blang Valley were used. The 29 -item DINESERV scale proposed by Stevens et al. (1995) was used in the study. The findings indicated that service quality positively influences customer satisfaction among Malaysian fast food consumers. Thus, it was concluded that when consumers' perceptions towards service quality is positive, customer satisfaction will be more favourable.

The finding of this study shows that Service reliability has significant effect on consumers' choice of fast-food outlets. This finding is in line with Alabar et al. (2014) who carried out a study on service quality and customer satisfaction in Nigerian mobile telephony. A sample of 532 mobile subscribers in Nigeria was used for the study. Pearson Product Correlation Coefficient was used. Data obtained were analysed using SPSS, version 20. The study revealed that SERVQUAL reliability dimension has significant effect on customer satisfaction. It was thus recommended that with ever-increasing influence of Nigeria communications commission (NCC), and the continuous complying which is one major strategy that the companies must adopt to remain cost effective.

The study finding also shows that service responsiveness have significant effect on consumers' choice of fast-food outlets. The finding affirmed other similar findings such as Mhlanga \& Tichaawa (2016), who carried out a study to determine the factors that affect consumer selection criteria in formal full-service restaurants. Primary data was collected with the help of a structured questionnaire administered to 400 respondents at selected formal full-service restaurants in Port Elizabeth. SPSS software was used to analyse the data. Findings revealed that compared with food quality/reliability, physical design and price, service responsiveness was the most important contributor to consumer choice. Thus, it was recommended service responsiveness should not be undermined by fast-food outlets

The finding of this study also reveals that service assurance has significant effect on consumers' choice of fastfood outlets. This finding is in tandem with Omar et al. (2016), in a quantitative study aimed at providing additional insight into the relationship between service quality and consumer choice using Malaysian customers of fast foods outlets. Questionnaire was developed to collect data from 411 respondents. Correlation analysis and hierarchical regressions were employed to analyse the data. Findings of the correlation analysis showed that all the five service quality attributes - tangibles, reliability, responsiveness, assurance and empathy have positive relationship with consumer choice.

The study further indicated that service empathy have significant effect on consumers' choice of fast-food outlets. The finding of this study is in line with Omar et al. (2016), in a qualitative study on Service Quality, Customers' Satisfaction and the Moderating Effects of Gender: A Study of Arabic Restaurants. The data was collected through questionnaire survey completed by 411 respondents. Correlation analysis and hierarchical regressions were employed to analyse the data. Findings of the correlation analysis shows that all the five service quality attributes - tangibles, reliability, responsiveness, assurance and empathy have positive relationship with customer satisfaction. It was concluded according to the findings that empathy has a strong positive correlation with customers' satisfaction while responsiveness has a weak positive relation with customers' satisfaction.

\section{Conclusion}

This study examined the effect of service quality delivery on consumers' choice of fast foods outlets in. The results obtained from the study indicate that service quality delivery in terms of tangibles, reliability, assurance, responsiveness as well as empathy significantly influenced consumers' choice of fast foods outlets in. Hence, in order to improve and ultimately maintain consumers' choice/preference, fast-food outlets must consistently deliver fast, strong and reliable service. Fast-food outlets should be more responsive to consumers' service requirements by rapidly eliciting and resolving consumers' enquiries and complaints. Fast-food outlets should ensure their personnel treat consumers with politeness and consideration at every point of service encounter. Fast-food outlets should ensure the appearance of physical facilities at their outlets is appropriate in order to provide confidence to consumers in their ability to provide the service required. The consumer's tastes and needs are dynamic, thus, every brand should constantly seek ways to offer freshness in order to remain relevant in the market place. 
Conflict of interest statement

The authors are in complete accord about the publication of this research. We hereby declare no conflict of interest.

Statement of authorship

The authors have a responsibility for the conception and design of the study. The authors have approved the final article.

\section{Acknowledgments}

We sincerely appreciate all the authors whose scholarly research articles and literature materials were cited in this study. We acknowledge the customers of fast-food outlets who responded to the research questionnaire which facilitated the completion of this research.

Etuk, A., Anyadighibe, J. A., Amadi, C., \& James, E. J. (2022). Service quality delivery and consumers' choice of fast-food outlets. International Research Journal of Management, IT and Social Sciences, 9(2), 264-273. https://doi.org/10.21744/irjmis.v9n2.2038 


\section{References}

Aaker, D. A., \& Jacobson, R. (1994). The financial information content of perceived quality. Journal of marketing research, 31(2), 191-201.

Alabar, T. T., Egena, O., \& Gbande, R. I. (2014). Service quality and customer satisfaction in Nigerian mobile telephony. International Proceedings of Economics Development and Research, 82, 108.

Anyanwu, J. C. (1993). Monetary economics: Theory, policy, and institutions. Hybrid Publishers.

Barrows, C. W., \& Powers, T. (2008). Introduction to management in the hospitality industry, study guide. John Wiley \& Sons.

Bartels, D. M., \& Johnson, E. J. (2015). Connecting cognition and consumer choice. Cognition, 135, 47-51. https://doi.org/10.1016/j.cognition.2014.11.024

Bougoure, U. S., \& Neu, M. K. (2010). Service quality in the Malaysian fast food industry: An examination using DINESERV. Services Marketing Quarterly, 31(2), 194-212.

Cronin Jr, J. J., \& Taylor, S. A. (1992). Measuring service quality: a reexamination and extension. Journal of marketing, 56(3), 55-68.

Decety, J., \& Cowell, J. M. (2014). The complex relation between morality and empathy. Trends in cognitive sciences, 18(7), 337-339. https://doi.org/10.1016/j.tics.2014.04.008

Fakokunde, T. O. (2010). Quality control and improvement practices among fast food retail outlets in southwestern Nigeria (Doctoral dissertation, University of Ilorin).

Foxall, G. R. (2003). The behavior analysis of consumer choice: An introduction to the special issue. Journal of economic psychology, 24(5), 581-588. https://doi.org/10.1016/S0167-4870(03)00002-3

Gilbert, G. R., \& Veloutsou, C. (2006). A cross-industry comparison of customer satisfaction. Journal of Services Marketing.

Huq, M. S., Fraass, B. A., Dunscombe, P. B., Gibbons Jr, J. P., Ibbott, G. S., Medin, P. M., ... \& Yorke, E. D. (2008). A method for evaluating quality assurance needs in radiation therapy. International Journal of Radiation Oncology* Biology* Physics, 71(1), S170-S173. https://doi.org/10.1016/j.ijrobp.2007.06.081

Hur, J., Raj, M., \& Riyanto, Y. E. (2006). Finance and trade: A cross-country empirical analysis on the impact of financial development and asset tangibility on international trade. World Development, 34(10), 1728-1741. https://doi.org/10.1016/j.worlddev.2006.02.003

Husted, J. A., Cook, R. J., Farewell, V. T., \& Gladman, D. D. (2000). Methods for assessing responsiveness: a critical review and recommendations. Journal of clinical epidemiology, 53(5), 459-468. https://doi.org/10.1016/S08954356(99)00206-1

Jain, S. K., \& Gupta, G. (2004). Measuring service quality: SERVQUAL vs. SERVPERF scales. Vikalpa, 29(2), 2538.

Lee, Y. L., \& Hing, N. (1995). Measuring quality in restaurant operations: an application of the SERVQUAL instrument. International Journal of Hospitality Management, 14(3-4), 293-310.

Mhlanga, O., \& Tichaawa, T. M. (2016). Guest expectations and experiences within selected hotels in Nelspruit, Mpumalanga Province of South Africa. African Journal for Physical Activity and Health Sciences (AJPHES), 22(42), 1185-1197.

Nikolich, M. A., \& Sparks, B. A. (1995). The hospitality service encounter: the role of communication. Hospitality Research Journal, 19(2), 43-56.

Oliver Richard, L. (1997). Satisfaction: A behavioral perspective on the consumer. New York 'NY: Irwin-McGrawHill.

Oliver, R. L. (1981). Measurement and evaluation of satisfaction processes in retail settings. Journal of retailing.

Omar, M. S., Ariffin, H. F., \& Ahmad, R. (2016). Service quality, customers' satisfaction and the moderating effects of gender: A study of Arabic restaurants. Procedia-Social and Behavioral Sciences, 224, 384-392.

Parasuraman, A., Zeithaml, V. A., \& Berry, L. (1988). SERVQUAL: A multiple-item scale for measuring consumer perceptions of service quality. 1988, 64(1), 12-40.

Parasuraman, A., Zeithaml, V. A., \& Berry, L. L. (1985). A conceptual model of service quality and its implications for future research. Journal of marketing, 49(4), 41-50.

Rackwitz, R. (2001). Reliability analysis-a review and some perspectives. Structural safety, 23(4), 365-395. https://doi.org/10.1016/S0167-4730(02)00009-7

Singer, T., \& Klimecki, O. M. (2014). Empathy and compassion. Current Biology, 24(18), R875-R878. https://doi.org/10.1016/j.cub.2014.06.054 
Sipayung, R. C., Salqaura, S. A., \& Sembiring, B. K. F. . (2021). Analysis of competitive advantage factors on business performance with sustainability performance as moderating variable in coffeenatics. International Journal of Business, Economics \& Management, 4(2), 319-334. https://doi.org/10.31295/ijbem.v4n2.1650

Stevens, P., Knutson, B., \& Patton, M. (1995). DINESERV: A tool for measuring service quality in restaurants. The Cornell Hotel and Restaurant Administration Quarterly, 36(2), 5-60.

Styvén, M. E. (2010). The need to touch: Exploring the link between music involvement and tangibility preference. Journal of Business Research, 63(9-10), 1088-1094. https://doi.org/10.1016/j.jbusres.2008.11.010

Wright, J. G., \& Young, N. L. (1997). A comparison of different indices of responsiveness. Journal of clinical epidemiology, 50(3), 239-246. https://doi.org/10.1016/S0895-4356(96)00373-3

Yulianti , N. M. D. R. ., \& Kintani , A. C. S. . (2020). Revitalization: new opportunities or new problems? The perspective of trader. International Journal of Business, Economics \& Management, 3(1), 177-185. https://doi.org/10.31295/ijbem.v3n1.185

Zeithaml, V. A. (1988). Consumer perceptions of price, quality, and value: a means-end model and synthesis of evidence. Journal of marketing, 52(3), 2-22.

Etuk, A., Anyadighibe, J. A., Amadi, C., \& James, E. J. (2022). Service quality delivery and consumers' choice of fast-food outlets. International Research Journal of Management, IT and Social Sciences, 9(2), 264-273. https://doi.org/10.21744/irjmis.v9n2.2038 